\title{
Genetic Diversity within Chinese Watermelon Ecotypes Compared with Germplasm from Other Countries
}

\author{
Yunyan Sheng \\ Horticulture College, Northeast Agricultural University, Harbin, Heilongjiang Province, P.R. China, \\ 150030; and Agricultural College, Heilongjiang Bayi Agricultural University, DaQing, Heilongjiang \\ Province, P.R. China, 163319 \\ Feishi Luan ${ }^{2}$ and Faxing Zhang \\ Horticulture College, Northeast Agricultural University, Harbin, Heilongjiang Province, P.R. China, \\ 150030
}

\author{
Angela R. Davis ${ }^{1}$ \\ Harris Moran Seed Co., Davis, CA 95618
}

AdDitional INDEX wORDs. Citrullus lanatus, genetic relationship, molecular markers, SSR, morphological traits

\begin{abstract}
Genetic diversity among 95 watermelon (Citrullus lanatus) ecotypes was evaluated and compared with representative Chinese, American, Japanese, and Russian watermelon cultigens, landraces, and a wild watermelon relative (Trichosanthes kirilowii). Open-pollinated, hybrid, and inbred lines were included for most of the ecotypes and are hereafter collectively referred to as cultigens unless an ecotype group is being discussed. Morphological characteristics (including days to flower, female to male flower ratio, branch number, fruit length and diameter ratio, fruit soluble solid content, fruit yield, and simple sequence repeat (SSR) markers were used to estimate genetic diversity. Of 398 watermelon primer pairs tested, $9.5 \%$ (38) produced polymerase chain reaction amplicons in watermelon. Of these 38 primer pairs, the average number of polymorphic bands among the 96 cultigens was 2.4 , even with 12 primer pairs demonstrating monomorphic banding patterns. Based on the SSR data, the genetic similarity coefficients were calculated and a dendrogram constructed. All cultigens were clustered to six groups. The wild species and landraces formed distant clusters from the cultivated watermelon. The genetic similarity coefficients within the Chinese cultigens ranged from 0.37 to 0.99 , but except for a wild relative to watermelon, most cultigens were closely related. The genetic distance among non-Chinese cultigens ranged from 0.67 to 0.91 with an average of 0.88. When combined morphological traits and molecular traits were assessed, Russian and U.S. fruit were more genetically similar to each other than to Chinese and Japanese cultigens. Crossing Russian and/or U.S. cultigens with Chinese or Japanese cultigens should thus improve genetic diversity and introduce new traits for the resulting watermelon cultigens.
\end{abstract}

Watermelon is an economically important crop of the cucurbitaceae family, which comprises two subfamilies, eight tribes, and $\approx 118$ genera and 825 species (Jeffrey, 1990). China is the greatest producer and consumer of watermelon in the world, producing significantly more fruit than the next leading producer, Turkey (Food and Agriculture Organization of the United Nations, 2010). The genus Citrullus consists of four known species, including $C$. lanatus, $C$. colocynthis, $C$. eccirrhosus, and C. rehmii (Jarret et al., 1997; Robinson and Decker Walters, 1997).

Watermelon has a long history of cultivation in China and the Middle East. By the 10th century, the crop was grown in China and southern Russia. This crop was introduced to the New World by the Spaniards in the 16th century and rapidly became popular with Native Americans (Gusmani and Wehner,

Received for publication 16 Nov. 2011. Accepted for publication 9 Apr. 2012. This work was supported by the China Agriculture Research system (CARS-26-02), 948 Project of the China Agriculture Ministry (2012-S17), Postdoctoral Research Foundation of Heilongjiang Province (LBH-Z10267), and the Scientific Research Fund of Heilongjiang Provincial Education Department (11551319).

${ }^{1}$ Formerly with the USDA-ARS. USDA is an equal opportunity provider and employer.

${ }^{2}$ Corresponding author. E-mail: luanfeishi@sina.com.
2007). In the United States, commercial watermelon is produced mainly in the southern states and Indiana.

Random amplified polymorphic DNA (RAPD) markers were used to estimate genetic diversity among watermelon cultivars (Lee et al., 1996; Solmaz et al., 2010) and to construct an initial genetic linkage map (Hashizume et al., 1993). Levi et al. (2005) identified RAPD markers for distinguishing between American watermelon cultivars of $C$. lanatus var. lanatus, $C$. lanatus var. citroides, and C. colocynthis. Levi et al. (2001) also demonstrated low genetic diversity among 46 heirloom cultivars of watermelon and concluded that American watermelon cultivars share a narrow genetic base. Restriction fragment length polymorphisms were also used to analyze Citrullus species chloroplast variability in wild and cultivated plants (Dane et al., 2004). Additional markers were detected using the RAPD procedure (Hashizume et al., 1993; Zhang et al., 1994). Jarret et al. (1997) determined genetic variation among PI accessions of $C$. lanatus var. lanatus, C. lanatus var. citroides, and $C$. colocynthis using simple sequence repeat length polymorphisms (SSRs). Subsequently, codominant simple sequence repeat markers were used to detect genetic diversity in watermelon (Patcharin et al., 2011). Recently, two types of molecular markers (RAPD and SSR) were used to estimate diversity in 81 seedlings 
from eight accessions of watermelon collected in Zimbabwe; five accessions were citron type ( $C$. lanatus var. citroides) and three C. lanatus var. lanatus (Mujaju et al., 2010). However, most of the previous work was performed on PI accessions from the U.S. Department of Agriculture germplasm collection, which only contains $\approx 20$ Chinese cultigens. A thorough understanding of the diversity of Chinese ecotypes has not been published.

Studying the process of domestication and colonization on watermelon will explain this crop's evolutionary diversification. In evolutionary ecology, an ecotype, sometimes called ecospecies, describes a genetically distinct geographic variety, population, or race within a species (or among closely related species), which is adapted to specific environmental conditions. Typically, diverse ecotypes exhibit phenotypic differences in morphology or physiology. Southern China includes Hubei, Fujian, Anhui, GuangDong, GuangXi, and Hainan provinces as well as islands of the South China Sea. The average temperature is $10^{\circ} \mathrm{C}$ and average precipitation is 1400 to $2400 \mathrm{~mm}$ per year. Northern China includes Heilongjiang, Henan, Gansu, Hebei, and Shanxi provinces including Beijing and Tianjing city. The area is a subhumid, warm-temperate, continental monsoon climate with dry cold winters and rainy summers. Northwest China is an arid zone, which includes Neimengo, Xinjiang, Ninxia, and Gansu provinces; the average precipitation is lower than $200 \mathrm{~mm}$ per year. Recognizing the geographical distribution of watermelon lineages will benefit future watermelon genetic exchanges and provide insight into different factors that shape watermelon genetic diversity. Although watermelon is distributed and cultivated worldwide, the genetic diversity and genetic relationship using DNA analysis are poorly described in China. In this study, open-pollinated, hybrid and inbred lines were included for most of the ecotypes and are hereafter collectively referred to as cultigens unless an ecotype group is being discussed. The objective of this study was to evaluate morphological variation and assess genetic diversity and genetic relationships among Chinese watermelon cultigens collected in different geographical regions compared with watermelon from other countries.

\section{Materials and Methods}

Plant materials. A total of 95 C. lanatus cultigens and one wild relative (T. kirilowii) were used in this study. These cultigens were selected because they represent a wide range of geographical origins and a range of important agronomic characteristics. Seeds from these ecologically diverse cultigens consist of the following watermelon ecotypes: a landrace of unknown origin (one), Northern Chinese (36), Southern Chinese (nine), Northwest Chinese $(23+$ one landrace + one T. kirilowii), Japanese (10), Russian (12), and American (three). Seed were obtained from various seed companies, academic and cultural institutes, and local growers (Table 1). All cultigens were grown and cultured widely for several years in the ecotype they are now listed under before they were collected for this study. Landraces (C. lanatus var. citroides) and the $T$. kirilowii germplasm were included in the study to supply diverse genetic and morphological material for comparison with the amount of relatedness between the domesticated watermelons.

DNA EXTraction. Twenty to 30 seeds of each watermelon cultigen were germinated in a greenhouse at the Xiangfang Experimental Station of Northeast Agricultural University, Harbin, China. Fifteen DNA samples were bulked for each cultigen.
Genomic DNA from leaf was extracted from all seedlings at the two- to three-leaf stage using a cetyltrimethyl ammonium bromide method (modified according to Luan et al., 2010). DNA samples were bulked for each watermelon cultigen to improve chances of detecting rare alleles. DNA quantity was determined by ultraviolet spectrophotometer (DNA = optical density $_{260} \times$ water volume $\times 50 \mu \mathrm{g} \cdot \mathrm{mL}^{-1}$ ) and diluted in water to a final concentration of $100 \mathrm{ng} \cdot \mu \mathrm{L}^{-1}$ and stored at $-20{ }^{\circ} \mathrm{C}$.

Simple Sequence RePeat amplification. Primer pairs, which generated 94 codominant SSR bands used in this study (Table 2), were from previously reported cucurbit sequences (Joobeur et al., 2006; Staub et al., 2007; Yi, 2002) and from Y.Q. Weng (University of Wisconsin, Madison, WI). Primers were synthesized by Shanghai Biotech Corp. (Shanghai, China) or were supplied by Y.Q. Weng. The primer sequences are listed in Table 2.

Polymerase chain reaction solutions were purchased from TaKaRa (Shanghai, China). The optimized $20-\mu \mathrm{L}$ reactions contained $180 \mathrm{ng}$ template DNA, $0.15 \mathrm{mmol} \cdot \mathrm{L}^{-1} \mathrm{dNTPs}, 0.25 \mu \mathrm{L}$ (0.5 pM) SSR primers, $0.2 \mathrm{U}$ Taq DNA polymerase, $2 \mu \mathrm{L}$ of $10 \times$ polymerase chain reaction (PCR) buffer $(50 \mathrm{mM} \mathrm{KCl}, 10 \mathrm{~mm}$ Tris-HCl, $2.5 \mathrm{~mm} \mathrm{MgCl}_{2}, \mathrm{pH}$ 8.3). Typical amplification parameters were used and PCR products $(5 \mu \mathrm{L})$ were resolved on $6 \%$ polyacrylamide gels at $80 \mathrm{~W}$ (DYY-12; Beijing First June Co., Beijing, China) for $2 \mathrm{~h}$ (Luan et al., 2010). A standard-sized marker (PD322; Tiangene Biotechnology Co., Beijing, China) was used to calculate the size of PCR products.

Morphological Evaluation. Seeds of 95 watermelon cultigens and the T. kirilowii were sown on 15 Apr. 2008. When cotyledons appeared, they were transplanted into plastic pots $(6 \times$ $8 \mathrm{~cm})$ in a plastic greenhouse $\left(18\right.$ to $\left.28^{\circ} \mathrm{C}\right)$. Forty-six d after sowing, most of the plants were at the three- to four-true leaf stage. Seedlings were again transplanted through plastic mulch at $0.6 \mathrm{~m}$ within-row spacing and $2 \mathrm{~m}$ between rows under plastic tunnels in black loamy (typical chernozem) soil at the Xiangfang Experimental Station of Northeast Agricultural University on 31 May 2008. Irrigation was through drip tape under plastic mulch. Five plants of each cultigen were planted per replication with three replications. One fruit was tested from each plant. Seedlings were arranged in a randomized complete block design consisting of three replications with five plants per plot. Plants were assessed for: branch number, which is the number of lateral branches counted on the main stem from the soil out to 30 nodes; anthesis or days to flower, which for this study was the number of days from transplanting until $50 \%$ of the plants in a plot were flowering; yield was calculated as yield per plant and was an average of all ripe fruit collected per ecotype divided by the total number of live plants representing that ecotype. Plants were also assessed for: fruit length:diameter ratio (L:D), as measured with calipers; sex ratio, determined by dividing the number of female flowers by the number of male flowers from the soil out to node 30 on the main stem; heart tissue (endocarp) soluble solids content (SSC) was determined for ripe fruit using a refractometer (July First Co., Beijing, China).

DATA ANALYSIS. Only strong, clean SSR primer generated bands expressing polymorphism were scored either as present (1) or absent (0). A binary data matrix obtained from scoring polymorphic bands was used to calculate Jaccard similarity coefficients (Jaccard, 1908) and then to estimate the genetic diversity among the different watermelon cultigens. The discriminatory power of each marker was assessed with polymorphic information content $(\mathrm{PIC})$. PIC was calculated as $\mathrm{PIC}=1-\sum\left(\mathrm{Pi}^{2}\right)$ 
Table 1. Watermelon cultigens used for genetic analysis with molecular markers and phenotypic traits.



Continued next page 
Table 1. Continued.

\begin{tabular}{|c|c|c|c|c|c|c|c|}
\hline No. & Origin & Ecotype $^{z}$ & Group & Cultivar/identifier & Population $^{\mathrm{y}}$ & Seed source ${ }^{\mathrm{x}}$ & Region $^{\mathrm{u}}$ \\
\hline 59 & China & $\mathrm{C}$ & IV & GY No. 004 & $\mathrm{~L}$ & GS & 4 \\
\hline 60 & China & $\mathrm{C}$ & IV & GY No. 005 & $\mathrm{~L}$ & GS & 4 \\
\hline 61 & China & $\mathrm{C}$ & IV & GY No. 006 & $\mathrm{~L}$ & GS & 4 \\
\hline 62 & China & $\mathrm{C}$ & IV & GY No. 007 & $\mathrm{~L}$ & GS & 4 \\
\hline 63 & China & $\mathrm{C}$ & IV & F No. 515-007 & $\mathrm{OP}$ & GS & 4 \\
\hline 64 & China & $\mathrm{C}$ & IV & No. 779 & $\mathrm{OP}$ & GS & 4 \\
\hline 67 & China & $\mathrm{C}$ & IV & Ji chang 3 & $\mathrm{~L}$ & $\mathrm{CJ}$ & 10 \\
\hline 68 & China & $\mathrm{C}$ & IV & Xin jiang 1 & $\mathrm{~L}$ & SHZ & 10 \\
\hline 69 & China & $\mathrm{C}$ & VI & Ye sheng zhong & $\mathrm{Tk}$ & WMZ & 10 \\
\hline 70 & China & $\mathrm{C}$ & V & Landrace No. 1 & LR & JXT & 1 \\
\hline 71 & China & Un & $\mathrm{V}$ & Landrace No. 2 & LR & WXQ & 1 \\
\hline 72 & Japan & $\mathrm{D}$ & IV & Te da hua lei & $\mathrm{H}$ & MT & 11 \\
\hline 76 & Japan $^{\mathrm{V}}$ & $\mathrm{D}$ & IV & Tai wan hei xiao bao & $\mathrm{H}$ & KY & 11 \\
\hline 77 & $\operatorname{Japan}^{\mathrm{V}}$ & $\mathrm{D}$ & IV & Te da lv chang 4 & $\mathrm{H}$ & KY & 11 \\
\hline 78 & Japan $^{\mathrm{V}}$ & $\mathrm{D}$ & IV & Za jiao hua chang 5 & $\mathrm{H}$ & KY & 11 \\
\hline 79 & $\operatorname{Japan}^{\mathrm{V}}$ & $\mathrm{D}$ & IV & Da fu gui & $\mathrm{H}$ & KY & 11 \\
\hline 80 & Japan & $\mathrm{D}$ & IV & Hei ling & $\mathrm{L}$ & MT & 11 \\
\hline 81 & Japan $^{\mathrm{V}}$ & $\mathrm{D}$ & IV & Peng shi te xiao gua & $\mathrm{L}$ & QQ & 1 \\
\hline 82 & United States & $\mathrm{E}$ & IV & Chong cha di lei wang & $\mathrm{H}$ & SY & 12 \\
\hline 83 & United States & $\mathrm{E}$ & IV & Chao tian di lei wang & $\mathrm{H}$ & SY & 12 \\
\hline 84 & United States & $\mathrm{E}$ & IV & Kang bing te da di lei wang & $\mathrm{H}$ & SY & 12 \\
\hline 85 & Russia & $\mathrm{F}$ & IV & Cuban & $\mathrm{OP}$ & WWLF & 13 \\
\hline 86 & Russia & $\mathrm{F}$ & IV & Excellent & OP & WWLF & 13 \\
\hline 87 & Russia & $\mathrm{F}$ & IV & Ali Kern Cisco & $\mathrm{OP}$ & WWLF & 13 \\
\hline 95 & Russia & $\mathrm{F}$ & IV & Russian-27 & $\mathrm{L}$ & WWLF & 13 \\
\hline 96 & Russia & $\mathrm{F}$ & IV & Russian-31 & $\mathrm{L}$ & WWLF & 13 \\
\hline
\end{tabular}

${ }^{\mathrm{z}} \mathrm{A}=$ Northern China; $\mathrm{B}=$ Southern China; $\mathrm{C}=$ Northwestern China; D = Japanese; E = United States; $\mathrm{F}=$ Russia; Un $=$ unknown.

${ }^{\mathrm{y}} \mathrm{OP}=$ open-pollinated cultivar; OPS = open-pollinated, which had been self pollinated; $\mathrm{L}=$ inbred line; $\mathrm{H}=$ commercial or experimental $\mathrm{F}_{1}$ hybrid; $\mathrm{Tk}=$ Trichosanthes kirilowii; $\mathrm{LR}=$ landrace.

${ }^{\mathrm{x}} \mathrm{AL}=$ Aolong Seed Co., Harbin, Heilongjiang Province, China; YY = Yu Yi Seed Co., Kaifeng, Henan Province, China; QX = Qing Xian Seed Co., Qing Xian Town, Hebei Province, China; GS = Agricultural Institute of Gansu Province, Lanzhou, Gansu Province, China; JXT = Mr. Jiang Xiang Tao (farmer), Daqing, Heilongjiang Province, China; OI = Orchard Institute of China in Zhengzhou of Chinese Academy of Agricultural Science (CAAS), Zhengzhou, Henan Province, China; QQ = Vegetable Institute of Qi Qi Haer, Qi Qi Haer, Heilongjiang Province, China; CAAS = CAAS, Peking, China; SN = Shen Niu Seed Co., Wu Chang, Wuhan Province, China; NJ = Nong Jia Seed Co., Fu Zhou, Fujiang Province, China; JQFN = Jin Qiu Feng Nian Seed Co., Xia Men, Fujian Province, China; KN = Ke Nong Seed Co., HeFei, An Hui Province, China; HZ = Hang Zhou Seed Co., Hangzhou, Jiangsu Province, China; XJ = Agricultural Institute of Xin Jiang Province, Wu Lu Muqi, Xinjiang Province, China; LD = farmers of Lin Dian Town, Daqing, Heilongjiang Province, China; HM = farmers in Ha Mi, Ha Mi, Xinjiang Province, China; MT = Maruei Trading Co., Tokyo; CJ = Chang Ji Research Institute on Melon, Changji, Xinjiang Province, China; SHZ= Shi Hezi University, Shi Hezi, Xinjiang Province, China; WMZ = Prof. Wu Ming Zhu of XinJing Agricultural Academic Institute, Wu Lu Muqi, XinJiang Province, China; WXQ = Dr. Wang Xi Qing Harbin Horticultural Institute of Agricultural Academic Institute of Heilongjiang Province, Harbin, Heilongjiang Province, China; SY = U.S. cultigens were imported and purchased from Sheng Yang Sheng Di Ya Seed Co., Shenyang, Liaoning Province, China. The original line 'Crimson Sweet' was crossed with female Chinese watermelon lines and the progeny was self-pollinated for multiple generations; KY = Known-you Seed Co., Ltd., Gao Xiong, Taiwan, China; WWLF = The N.I. Vavilov Institute of Plant Industry, Klas Rafael, Moscow, Russia.

${ }^{w} 1$ = Heilongjiang Province, China; 2 = Henan Province, China; 3 = Hebei Province; China, 4 = Gansu Province, China; $5=$ Beijing; $6=$ Hubei Province, China; $7=$ Fujian Province; China; $8=$ Anhui Province, China; $9=$ Zhejiang Province, China; $10=$ Xinjing Province, China; $11=$ Japan; 12 = United States; 13 = Russia.

${ }^{v}$ Chinese germplasm that were imported to Japan, put into breeding programs there, and now perform well in that region. 
Table 2. Primer sequences used in this study and the number of polymorphic polymerase chain reaction bands generated from 38 primer pairs used for detecting genetic diversity in watermelon cultigens. ${ }^{\mathrm{z}}$

\begin{tabular}{|c|c|c|c|c|c|c|}
\hline No. & Markers & Forward primer & Reverse primer & $\begin{array}{c}\text { Alleles } \\
\text { (no.) }\end{array}$ & PIC & Source \\
\hline 1 & MCPI-12 & GGAGTAGTGGTGGAGACATGG & TCCTTTCTCTTTCGCAAACTTC & 1 & 0 & Joobeur et al., 2006 \\
\hline 2 & MCPI-15 & GCAAAATGCAACTGTTTATCG & CCATTATGATTTCAATCAATCTCC & 3 & 0.049 & Joobeur et al., 2006 \\
\hline 4 & MCPI-41 & AGGTGGTATGTCGCTCATCC & GTGGGAGATGTGTGAGCTTG & 2 & 0.275 & Joobeur et al., 2006 \\
\hline 5 & III & GCTAACGTATGCGTAGTACGTAG & ATCGGGCTATACCGGAATTCGGC & 1 & 0 & Yi, 2002 \\
\hline 6 & IV & СТTTTTСTTCTGATTTGACTGG & СТTTTTCTTCTGATTTGACTGG & 2 & 0.054 & Yi, 2002 \\
\hline 8 & $\mathrm{XX}$ & TTTACCAAAAAGGTGTGAGC & TTTACCAAAAAGGTGTGAGC & 1 & 0 & Yi, 2002 \\
\hline 9 & $\mathrm{XI}$ & TTAAATCCCAAAGACATGGCG & TTCAACTACAGCAAGGTCAGG & 3 & 0.412 & Yi, 2002 \\
\hline 10 & XII & ATTGCCCAACTAAACTAAACC & CCGACATTGAAAACCAACTTC & 4 & 0.488 & Yi, 2002 \\
\hline 11 & CMACC146 & TTACTGGGTTTTGCCGATTT & AATTCCGTATTCAACTCTCC & 1 & 0 & Yi, 2002 \\
\hline 12 & CMAT35 & GTGGGTCATCATTATTGTTA & GCTTTTAGCCTATTAAGTTGC & 6 & 0.723 & Staub et al., 2007 \\
\hline 13 & CSCCT571 & СCTTTCTGCTGTTTCTTCTTC & GAAGGAAGGAGTGAGGGGAAG & 1 & 0 & Staub et al., 2007 \\
\hline 18 & SSR01253 & CGCTGGATTTGTTTGTGAAAT & AATGTCGGGGAGTGTCACAT & 4 & 0.467 & Y.Q. Weng \\
\hline 19 & SSR16238 & TCCGGATCTCTACCAAATGAA & TCAGAGCATAAAACCAGTGTGT & 6 & 0.659 & Y.Q. Weng \\
\hline 20 & SSR20338 & TGATGATCCCACACGTCAAG & TGGTGAAAGGTGGTGTGAGA & 1 & 0 & Y.Q. Weng \\
\hline 21 & SSR22874 & CAACCCCCAAGCTCTGATAA & ATTGGAGAGTGCTATTGGGG & 1 & 0 & Y.Q. Weng \\
\hline 22 & SSR30236 & TCAATTAAACGAGTGGCAAAGA & GCCACGGGTTGACTACAAAT & 2 & 0.244 & Y.Q. Weng \\
\hline 23 & SSR13292 & AGACAGGGAAATCGCAGAGA & GGTTAAAGGACGTCGGGATT & 3 & 0.165 & Y.Q. Weng \\
\hline 24 & SSR03015 & TCTAGGATTAATTCCACATTCACAA & TTTACCGTGGGAGAGACTGG & 1 & 0 & Y.Q. Weng \\
\hline 25 & SSR20270 & TTGGGATGTAGATGTCCGGT & TCСССАAТCСАAСТСССТАТ & 3 & 0.138 & Y.Q. Weng \\
\hline 26 & SSR01904 & TCTGAGTGTTTGACGGATGG & CAATCCCTTTGAGCCAGAGA & 4 & 0.435 & Y.Q. Weng \\
\hline 27 & SSR21186 & TTTGAGCAACACTTCGCAAC & GCATGTTTTCATGTCATTGGA & 3 & 0.145 & Y.Q. Weng \\
\hline 28 & SSR00842 & CGCCCAAATTGAACGAATAA & CCTCCGCCTTTCTTTCTTTT & 5 & 0.542 & Y.Q. Weng \\
\hline 36 & SSR11340 & ATATGTGTGTCGTGTTCCGC & CAGATTTCCGAGAGGGAAAA & 2 & 0.0153 & Y.Q. Weng \\
\hline 37 & SSR23487 & TGTTTCAAGGTGCTGACCTG & CCACAACAACAAAAGAATGTGAA & 1 & 0 & Y.Q. Weng \\
\hline 38 & SSR21708 & CGCAATTATGATTACAATGTTCA & AGTGCACCAATTCGAATAAAA & 1 & 0 & Y.Q. Weng \\
\hline
\end{tabular}

${ }^{\mathrm{z}}$ The discriminatory power of each primer pair was assessed with polymorphic information content $(\mathrm{PIC}) . \mathrm{PIC}$ was calculated as $\mathrm{PIC}=1-\sum\left(\mathrm{Pi}^{2}\right)$, where $P_{i}$ is the frequency of the $i$ th alleles detected in all watermelon cultigens (Anderson et al., 1992).

${ }^{y}$ Y.Q. Weng, USDA-ARS, University of Wisconsin, Madison, WI.

in which $\mathrm{P}_{\mathrm{i}}$ is the frequency of the $i$ th alleles detected in all watermelon cultigens (Anderson et al., 1992). Additionally, cluster analyses were performed based on the software package PHYLIP 3.66 (Felsenstein, 1989). Specifically, 1000 bootstrap trials were performed on the data using SEQBOOT after which RESTDIST was used to construct pairwise distance matrices based on Nei and Li (1979), then subjected to neighbor-joining cluster analysis (Saitou and Nei, 1987) from which a consensus tree was generated with CONSENSE. Morphological data were subjected to analyses of least significant difference mean comparisons, means, SD, CV, and significant test and one-way analysis of variance were calculated to describe all cultigen variation. The principal component analysis (PCA) and cluster analysis of the morphological traits were performed based on SAS/STAT (Version 6; SAS Institute, Cary, NC).

\section{Results and Discussion}

MorPhOlOGICAL GRouping. Branch number separated the T. kirilowii (17.0) from all the C. lanatus and separated Southern Chinese ecotypes and Japanese cultigens (6.4) from the landrace and T. kirilowii (Table 3). Days to flower separated the Southern China ecotypes, Japanese, and U.S. cultigens (38.6, 40.0, and 41.6, respectively) from the Northern Chinese ecotypes, the landrace (52.4 and 52.0, respectively), and the T. kirilowii (68.0). Yield had two distinct outlying groups, the $T$. kirilowii with a value of $0.40 \mathrm{~kg}$ and the Russian cultigens with the highest yield $(72.7 \mathrm{~kg}$ ). Soluble solids separate the T. kirilowii (SSC of 3.0) from all of the C. lanatus, all of which had similar mean SSC content (8.8 to 10.0). No significant difference was demonstrated between groups for L:D. Only T. kirilowii was 
Table 3. Principal component analysis of watermelon and reference cultigens averaged for all varieties and all replications per ecotype.

\begin{tabular}{|c|c|c|c|c|c|c|}
\hline$\overline{\text { Ecotype }}$ & Branches (no.) $^{\mathrm{z}}$ & Time to flower $(\mathrm{d})^{\mathrm{y}}$ & ${\text { Yield }(\mathrm{kg} / \text { plant })^{\mathrm{x}}}$ & $\mathrm{SSC}^{\mathrm{w}}$ & $\mathrm{L}: \mathrm{D}^{\mathrm{v}}$ & $\overline{\text { Sex ratio }(F: M)^{\mathrm{u}}}$ \\
\hline Northern China & 6.9 & 52.4 & 64.1 & 8.8 & 3.4 & 7.2 \\
\hline Northwest & 7.0 & 44.3 & 61.1 & 9.2 & 3.4 & 6.8 \\
\hline United States & 7.3 & 41.6 & 71.9 & 10.0 & 3.7 & 7.0 \\
\hline Russia & 7.2 & 45.4 & 72.7 & 9.9 & 4.0 & 7.3 \\
\hline Trichosanthes kirilowii & 17.0 & 68.0 & 0.4 & 3.0 & 4.0 & 5.0 \\
\hline Grand mean & 6.9 & 43.7 & 63.5 & 8.6 & 3.4 & 6.8 \\
\hline LSD $(0.05)$ & 1.4 & 4.3 & 22.2 & 1.2 & 0.9 & 1.3 \\
\hline $\mathrm{CV}(\%)$ & 0.2 & 0.1 & 0.2 & 0.1 & 0.4 & 0.3 \\
\hline Significance test ${ }^{\mathrm{t}}$ & $8.7^{* * \mathrm{t}}$ & $36.6 * *$ & $6.5^{* *}$ & $2.0 * *$ & 1.1 & $1.8^{* *}$ \\
\hline
\end{tabular}

${ }^{\mathrm{z}}$ Number of lateral branches counted on the main stem from roots out to 30 nodes.

${ }^{y}$ Number of days from transplanting to when $50 \%$ of the plants have reached anthesis.

xAverage of all ripe fruit collected per ecotype divided by the total number of plants representing that ecotype.

${ }^{\mathrm{w}}$ Flesh soluble solids content, average soluble solids content in heart tissue (endocarp).

${ }^{\vee}$ Length-to-diameter ratio, average fruit length/average diameter ratio from three harvests.

"Average number of female flowers/the number of male flowers.

t*, ** indicates that the difference is significant by analysis of variance at the 0.05 and $0.01 P$ level, respectively.

$\mathrm{LSD}=$ least significant difference.

statistically different between the other groups when comparing sex ratio. All characteristics were measured only in one environment in one year. Subsequent tests in multiple locations may change the morphological groupings.

Morphological data were collectively analyzed with PCA, and $83 \%$ of the observed variation was explained [ $64 \%$ and $20 \%$ in principal components 1 and 2 , respectively (Table 3 )]. Yield per plant and sex ratio were primary contributors to principal components 1 and 2, respectively. Landrace and $T$. kirilowii were similar to each other but different from other watermelon cultigens examined. Nevertheless, Russian and American ecotypes were more similar to each other than to Chinese watermelon cultigens. In contrast, Northwest Chinese and Japanese ecotypes were morphologically similar for the traits examined, although Northeast Chinese and South Chinese ecotypes were similar to each other and differed from Japanese, Russian, and American ecotypes for all traits examined (data not shown).

PCA for six morphological traits revealed similar groupings as cluster analysis (Figs. 1 and 2). T. kirilowii and the landrace grouped separately. Additionally, the American cultigens were more similar to Russian than to Japanese cultigens although all cultigens from Japan, Russia, America, and Northwest China were grouped into the same cluster (Cluster IV).

Molecular Grouping. Initially, 398 pairs of SSR primers were used to estimate genetic diversity among 95 watermelon cultigens from different ecological environments, which include inbred lines, hybrids, open-pollinated, landraces, and one T. kirilowii. A total of 38 primer pairs demonstrated polymorphism. These primer pairs detected 94 putative alleles with an average of 2.4 alleles per SSR locus (Table 2). The PIC values of these markers ranged from 0 to 0.723 with an average of 0.198 (Table 3). Genetic similarity coefficients were calculated for estimated genetic diversity among the 96 cultigens tested. Genetic similarities ranged between 0.99 in the most closely related cultigens (Dongmi 001 and Aomi 001) to 0.37 for the most distant [T. kirilowii and Gy0041 (Northwestern ecological types)]. Most cultigens were closely related. The



Fig. 1. Principal component analysis of watermelon germplasm using mean values of six morphological traits to graphically represent the clustering of the phenotypes (branch number, days to flower, yield, soluble solid content, length-to-diameter ratio, female-to-male flower ratio). The box represents the relationship between ecotypes when comparing compiled data from different regions, whereas the clusters represent how each ecotype group related to all others.

genetic distance among non-Chinese cultigens ranged from 0.67 to 0.91 with an average of 0.88 . Cluster analysis $(\mathrm{JC}=$ 0.74) using SSR data indicated that all Northern Chinese ecotypes tested (except No. 18) grouped in Cluster I containing 35 watermelon cultigens. Cluster II consisted of eight cultigens from Southern China (Nos. 37, 38, 39, 41, 42, 43, 44, and 45) and two cultigens from Northwest China (Nos. 46 and 48). No. 18 and No. 40, Northern and Southern Chinese types, were grouped into Group III, because these two watermelon cultigens are grown for and were thus bred for use as a vegetable (hard flesh and low sugar type for cooking); this is understandable. The largest cluster contained 46 cultigens, Group IV consisted of all 




Fig. 2. Cluster analysis of watermelon germplasm using simple sequence repeat (SSR) markers. Northern Chinese ecotypes (except No. 18) are grouped in Cluster I, which consisted of 35 watermelon cultigens. Eight cultigens from Southern China and two cultigens from Northwest China (Nos. 46 and 48) comprised Cluster II. Two types segregated out into Cluster III are Northern and Southern Chinese ecotypes. The largest Cluster IV consisted of all cultigens from Northwestern China (except Nos. 46 and 48), Japan, Russia, and the United States. Two landrace cultigens grouped to Cluster $\mathrm{V}$ and Trichosanthes kirilowii formed its own Cluster VI. The Arabic numbers represent the individual samples and are discussed in the text. The watermelons were divided into six groups. Bootstrap sampling of alleles was carried out for 1000 replications. The numbers at the forks indicate the number of times that individual or group to the right of the fork occurred among the tree of 1000 trees.

cultigens from Northwest China (except Nos. 46 and 48) and all cultigens from Japan, Russia, and the United States. This cluster consisted of three subgroups, which included Subgroup 1 (all cultigens from Northwest China except Nos. 46 and 48), Subgroup 2 (all cultigens from Japan), and the third subgroup (all cultigens from the United States and Russia). The results indicated that the SSR markers used can separate the cultigens by ecotypes. The two landraces (Nos. 70 and 71) grouped to Cluster $\mathrm{V}$ and the T. kirilowii was in the last cluster (VI) (Fig. 2). T. kirilowii is equally dissimilar to all the other cultigens (average $\mathrm{JC}=0.51$ ) and Northern China and Southern China watermelon cultigens were the most similar (average $\mathrm{JC}=0.73$ ). U.S. and Russian cultigens were the most similar (average $\mathrm{JC}=0.77$ ), even more similar than the Japanese cultigens, which grouped in the same cluster. Landraces were genetically similar (average $\mathrm{JC}=0.69$ ) and were more similar to Northwestern Chinese ecotypes, and Russian, U.S., and Japanese cultigens, than to Northern or Southern Chinese ecotypes. Additionally, Northern and Southern Chinese ecotypes could be used as diverse genetic material for Russian, U.S., Japanese, and Northwestern Chinese breeding lines.

Watermelon germplasm resources present a range of morphological traits. Unfortunately, germplasm cannot be clearly separated unless many 
traits are used for comparison. This is likely the result of the crop's narrow genetic diversity resulting from centuries of intensive selection of horticulturally acceptable traits across many ecotypes. Our results are similar to Levi et al. (2000) in that the landrace had some morphological characteristics of $C$. lanatus var. lanatus but was easily divided into a separate group when comparing all morphological traits and when comparing molecular makers. In general, marker analysis grouped the ecotypes in a similar manner as the phenotypic grouping but with a few outliers, demonstrating both methods produce comparable estimates of genetic diversity in watermelon. When combined morphological traits and when molecular traits are assessed, Russian and U.S. fruit are more genetically similar to each other than to Chinese and Japanese cultigens. Japanese cultigens are as similar to the various Chinese ecotypes as they are to one another. Crossing Russian and/or U.S. cultigens to Chinese ecotypes or Japanese cultigens should improve genetic diversity of the resulting watermelon lines.

\section{Literature Cited}

Anderson, J.A., G.A. Churchill, J.E. Autrique, S.D. Tanksley, and M.E. Sorrells. 1992. Optimizing parental selection for genetic linkage maps. Genome 36:181-186.

Dane, F., P. Lang, and R. Bakhtiyarova. 2004. Comparative analysis of chloroplast DNA variability in wild and cultivated Citrullus species. Theor. Appl. Genet. 108:958-966.

Felsenstein, J. 1989. PHYLIP_-Phylogeny inference package (Version 3.2). Cladistics 5:164-166.

Food and Agriculture Organization of the United Nations. 2010. Top production quantity in the world, Title 17. Top production on watermelons in 2010. 18 Apr. 2012. <http://faostat.fao.org/site/339/ default.aspx $>$.

Gusmani, G. and T.C. Wehner. 2007. Heritability and genetic variance estimates for fruit weight in watermelon. HortScience 42:1332-1336.

Hashizume, T., T. Sato, and M. Hirai. 1993. Determination of genetic purity of hybrid seed in watermelon (Citrullus lanatus) and tomato (Lycopersicon esculentum) using random amplified polymorphic DNA (RAPD). Jpn. J. Breeding 43:367-375.

Jaccard, P. 1908. Nouvelles researches sur la distribution florale. Bulletin de la Sociète Vaudense des Sciences Naturelles 44:223-270.

Jarret, R.L., L.C. Merrick, T. Holms, J. Evans, and M.K. Aradhya. 1997. Simple sequence repeats in watermelon [Citrullus lanatus (Thunb.) Matsum. and Nakai]. Genome 40:433-441.

Jeffrey, C. 1990. Systematics of the cucurbitaceae: An overview, p. 2-9. In: Bates, D.M., R.W. Robinson, and C. Jeffrey (eds.). Biology and utilization of the cucurbitaceae. Cornell University Press, Ithaca, NY.
Joobeur, T., G. Gusmani, X. Zhang, A. Levi, Y. Xu, T.C. Wehner, M. Oliver, and R.A. Dean. 2006. Construction of a watermelon BAC library and identification of SSRs anchored to melon or Arabidopsis genomes. Theor. Appl. Genet. 112:553-562.

Lee, S.J., J.S. Shin, K.W. Park, and Y.P. Hong. 1996. Detection of genetic diversity using RAPD-PCR and sugar analysis in watermelon [Citrullus lanatus (Thunb.) Mansf.] germplasm. Theor. Appl. Genet. 92:719-725.

Levi, A., C.E. Thomas, A.P. Keinath, and T.C. Wehner. 2000. Estimation of genetic diversity among Citrullus accessions using RAPD markers. Acta Hort. 510:385-390.

Levi, A., C.E. Thomas, A.P. Keinath, and T.C. Wehner. 2001. Genetic diversity among watermelon (Citrullus lanatus and Citrullus colocynthis) accessions. Genet. Resources Crop Evol. 48:559-566.

Levi, A., C.E. Thomas, A.M. Simmons, and J.A. Thies. 2005. Analysis based on RAPD and ISSR markers reveals closer similarities among Citrullus and Cucumis species than with Praecitrullus fistulosus (Stocks). Pangalo. Genet. Resources Crop Evol. 52:465-472.

Luan, F., Y. Sheng, Y. Wang, and J.E. Staub. 2010. Performance of melon hybrids derived from parents of diverse geographic origin. Euphytica 173:1-16.

Mujaju, C., J. Sehic, G. Werlemark, L. Garkava-Gustavsson, M. Fatih, and H. Nybom. 2010. Genetic diversity in watermelon (Citrullus lanatus) landraces from Zimbabwe revealed by RAPD and SSR markers. Hereditas 147:142-153.

Nei, M. and W. Li. 1979. Mathematical model for studying genetic variation in terms of restriction endonucleases. Proc. Natl. Acad. Sci. USA 76:5269-5273.

Patcharin, T., P. Taeprayoon, Y. Hadkam, and P. Srinives. 2011. Genetic diversity among Jatropha and Jatropha-related species based on ISSR markers. Plant Mol. Biol. Rpt. 29:252-264.

Robinson, R.W. and D.S. Decker-Walters. 1997. Cucurbits. CAB International, New York, NY.

Saitou, N. and M. Nei. 1987. The neighbor-joining method: A new method for reconstructing phylogenetic trees. Mol. Biol. Evol. 4:406-425.

Solmaz, I., N. Sari, Y. Aka-Kacar, and N. Yesim Yalcin-Mendi. 2010. The genetic characterization of Turkish watermelon (Citrullus lanatus) accessions using RAPD markers. Genet. Resources Crop Evol. 57:763-771.

Staub, J.E., F. Luan, and I. Delannay. 2007. Genetic diversity in Chinese melon (Cucumis melo L.). HortScience 42:856-857.

$\mathrm{Yi}$, K. 2002. Construction of genetic linkage map and localization of main agronomic characters in watermelon [Citrullus lanatus (Thunb.) Matsum \& Nadai]. PhD diss., Hunan Agr. Univ., Chang Sha, China.

Zhang, X.P., H.T. Skorupaka, and B.B. Rhodes. 1994. Cytological expression in the male-sterile $m s$ mutant in watermelon. Heredity $85: 279-285$. 